\title{
Highlights from APSA's 15th Teaching and Learning Conference
}

$\mathrm{F}$ rom February 2-4, attendees gathered in Baltimore, Maryland for the 15th Teaching and Learning Conference. The program committee organized a very dynamic program of sessions and workshops around the theme "Teaching Politics as a Public Good: Citizenship and Civic Engagement in the Classroom." The program opened with the Keynote Address by Elizabeth Beaumont of the University of California, Santa Cruz.

During this keynote session, APSA President Kathleen Thelen of the Massachusetts Institute of Technology offered remarks and presented two prestigious awards: the 2018 CQ Press Award for Teaching Innovation to winner Eric Loepp, University of Wisconsin, Whitewater, and the Michael Brintnall Award to winner Janet Reilly, Sarah Lawrence College.
The 2018 APSA Teaching and Learning Conference (TLC) focused on promoting greater understanding of how to create an engaging environment for all students in the classroom. The conference was organized using a working group model which permits in-depth discussion and debate on pedagogical issues relevant to the political science discipline. This year the main track themes addressed issues of civic engagement, disciplinary curriculum, teaching the liberal arts and research, writing, and information literacy, use of simulations and games, and the virtually and technologically enhanced classroom. The panels and workshops presented research on best practices in political science education and how all teachers can effectively train students to think analytically, write effectively, and evaluate, consume, and generate knowledge.
APSA staff and TLC organizers thank those who participated and those who support APSA's commitment to excellence in the scholarship of teaching and learning. The TLC is a central part of APSA programs supporting the practice and scholarship of teaching and learning. As the TLC continues to evolve, APSA is excited to promote the TLC mini-conference that will take place September 1 at the 2018 APSA Annual Meeting.

For over a decade, TLC has brought together educators who use this event to generate ideas and develop techniques which stimulate conversation in the discipline about pedagogical research and innovations. This year continued that tradition. The proceedings of the meeting will be shared discipline-wide through the track summaries featured in the July issue of PS: Political Science \& Politics. .
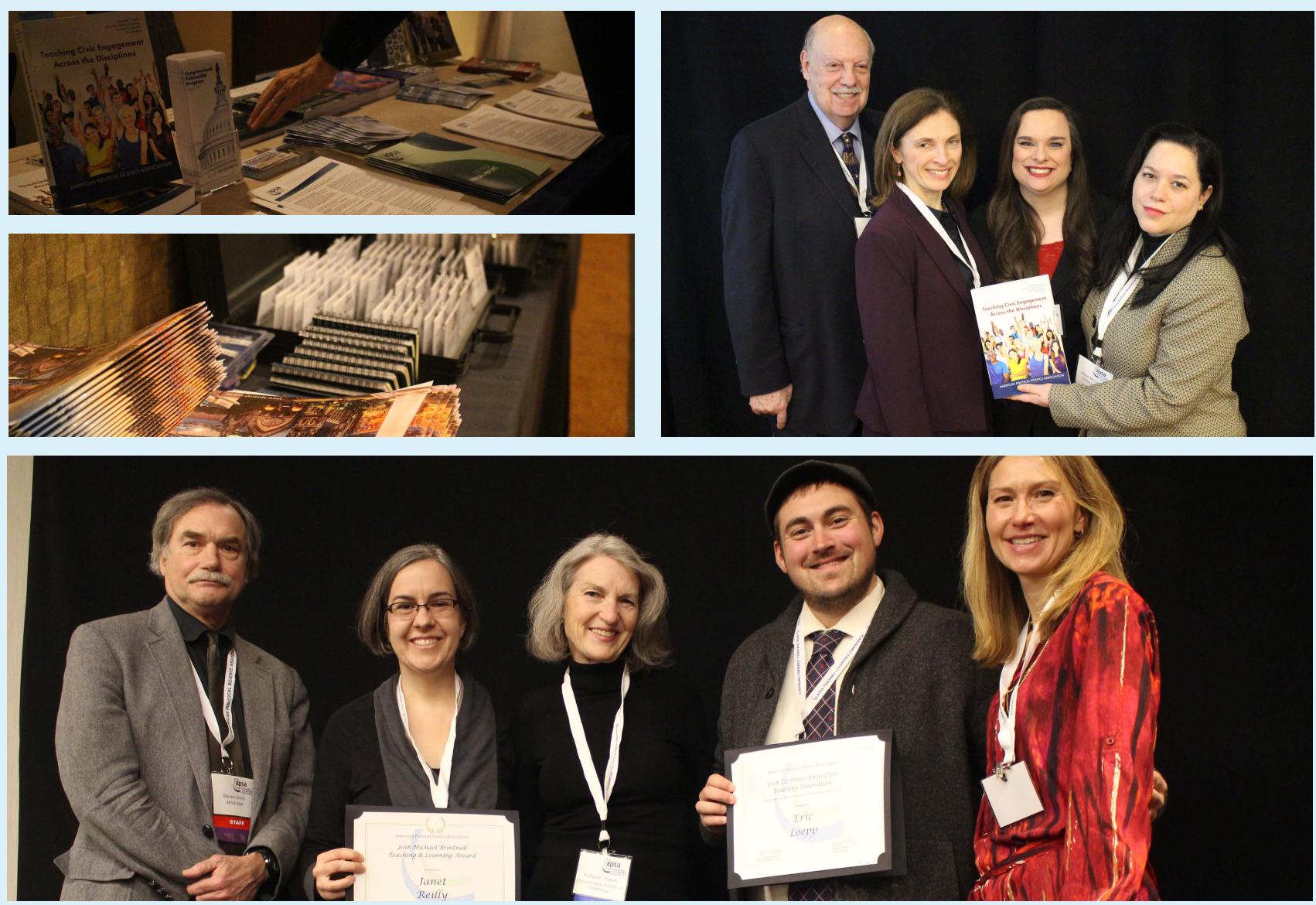

Clockwise from the top left: A glimpse at the APSA registration and promotional tables. The editors of "Teaching Civic Engagement Across the Disciplines" (from left to right) Dick Simpson, Elizabeth Matto, Elizabeth Bennion, and Alison Rios Millett McCartney pose with the book after presenting a plenary session on civic engagement. APSA Executive Director Steven Rathgeb Smith (far left) poses with (from left to right) Brintnell Award winner Janet Reilly, APSA President Kathleen Thelen, CQ Sage Award winner Eric Loepp, and keynote speaker Elizabeth Beaumont. 